\title{
Differential temperature effects on the efficiency of carbon pathways in Antarctic marine benthos
}

\author{
Wolfgang Reichardt
}

Institut für Meereskunde an der Universität Kiel, Düsternbrooker Weg 20, D-2300 Kiel, Federal Republic of Germany

\begin{abstract}
Enzymatic activities and metabolic rates, which play key roles in benthic carbon turnover, were characterized with respect to cold adaptation in aphotic Antarctic sediments. Temperature op:ima for $\mathrm{CO}_{2}$ dark fixation and mineralization of glucose coincided largely with the maximal growth temperatures of obligate psychrophilic bacteria (at $20^{\circ} \mathrm{C}$ and below). On the other hand, predominantly extracellular enzyme activities involved in the conversion of particulate organic matter (POM) into dissolved organic matter (DOM), such as scleroprotease and chitinase, had considerably higher temperature optima $\left(40\right.$ to $\left.55^{\circ} \mathrm{C}\right)$. This lack of cold adaptation at the activity level was less strongly expressed in other hydrolases (sulfatase, alkaline phosphatase). Substrate affinities or activation energies were often inapplicable or insignificant as a potential measure of temperature adaptation. Alternative strategies of cold adaptation may be relevant at the level of synthesis of POM-solubilizing enzymes.
\end{abstract}

\section{INTRODUCTION}

As more than $90 \%$ of the marne environment is permanently exposed to temperatures below $5^{\circ} \mathrm{C}$, the efficiency of biogeochemical cycles is affected by the extent of cold adaptation of their key processes. To understand the enzymatic control of carbon turnover at permanently low temperatures, it is important to know whether different biogeochemical pathways are dependent on different degrees of cold adaptation.

Numerous investigations have dealt with autecological aspects of cold adaptation (e.g. Arnaud 1977, George 1977, Baross \& Morita 1978, Somero et al. 1983). However, little is known about the temperature characteristics of key biogeochemical processes in stable cold marine environments such as the Antarctic Ocean (Pomeroy et al. 1969, Holm-Hansen et al. 1977. Morita et al. 1977).

Utilization of dissolved organic matter (DOM) by Antarctic marine microheterotrophs exhibits a temperature dependence similar to growth rates of psychrophilic bacteria (Gillespie et al. 1976, Baross \& Morita 1978. Hodson et al. 1981). An even more effective temperature acclimation seems to apply to phatosynthetic processes (Neori \& Holm-Hansen 1982, Li et al. 1984). Although the input of detrital particulate organic matter (POM) is extremely important for car- bon budgets of aphotic sediments, information on temperature characteristics of the primary enzymatic processes involved in POM degradation is largely lacking. Investigations in freshwater environments seem to indicate that conversion of organic detritus particles to DOM is primarily a temperature-controlled process (Godshalk \& Wetzel 1977).

It is conceivable that benthic carbon budgets are severely affected and controlled by different temperature adaptation on subsequent biogeochemical pathways. Lack of temperature compensation at the level of primary decomposition processes could turn manne sediments into sinks for POM. The permanently cold Antarctic benthic environment offered an ideal study site to determine the extent of physiologically extreme temperature adaptation for major pathways of the carbon cycle.

Parameters selected to characterize pertinent catabolic and anabolic processes of the sediment biota included POM-solubilizing and hydrolyzing enzyme activities in sediment extracts as well as in vivo rates of glucose mineralization and dark fixation of carbon dioxide. Temperature effects were studied with respect to both temperature optima and kinetic constants.

Poor cold adaptation was noted for the activities of hydrolytic enzymes related to key primary decomposition processes. Hence, decomposition of organic matter 
in the permanently cold benthic environments is likely to be restricted ('temperature-controlled') at its initial steps, unless the lack of enzymatic adaptation is compensated for by an increased production or accumulation of the pertinent enzymes.

\section{MATERIAL AND METHODS}

Sampling area. Sediment samples were obtained with a modified Reineck box core sampler on 2 cruises of RV 'Polarstern' in the Bransfield Strait and NW Weddell Sea, Antarctica, from 28 Nov to 18 Dec 1983, and from 18 Nov to 4 Dec 1984 (Table 1).

Experiments. Subsamples were punched out with plexiglass tubes $(6 \mathrm{~cm}$ inner diameter) for shipboard experiments in a refrigerated $\left(0^{\circ} \mathrm{C}\right)$ laboratory container. To obtain vertical activity profiles, sediment slices of $1 \mathrm{~cm}$ thickness were incubated at in situ temperatures $\left(0^{\circ}\right)$. Material from the surface layers $(0$ to $2 \mathrm{~cm}$ ) was used in temperature gradient experiments.

These were carried out in triplicate with duplicate blanks using a series of temperature-controlled water baths. These were run over both a narrow $(-0.5$ to $20^{\circ} \mathrm{C}$ ) and a wide $\left(0\right.$ to $\left.65^{\circ} \mathrm{C}\right)$ temperature range at intervals of 3 to $4 \mathrm{C}^{\circ}$ and 5 to $10 \mathrm{C}^{\circ}$, respectively. For comparison with environments that are only seasonally cold, late winter samples from Kiel Bay sediment (1 to $2^{\circ} \mathrm{C}$ ) were used in similar experiments.

Enzyme activities. Enzymatic activities were measured after cold extraction $\left(30\right.$ min at $0^{\circ} \mathrm{C}$ on a shaking machine) of $20 \mathrm{~cm}^{3}$ of sediment with $80 \mathrm{ml}$ of $2 \%$ triton-X100 containing $2 \mathrm{~g} \mathrm{l}^{-1}$ of polyvinylpyrrolidone in tris- $\mathrm{HCl}(10 \mathrm{mM}, \mathrm{pH} 7.5)$-buffered artificial seawater. The following enzyme assays were selected because of the significance of these enzymes in the

Table 1. Survey of box core stations

\begin{tabular}{|c|c|c|c|}
\hline \multicolumn{4}{|c|}{28 Nov-18 Dec, 1983} \\
\hline $\begin{array}{c}\text { Station } \\
\text { number }\end{array}$ & $\begin{array}{l}\text { Water depth } \\
\text { (m) }\end{array}$ & \multicolumn{2}{|c|}{ Coordinates } \\
\hline 270 & 113 & $62^{\circ} 47 \mathrm{~S}$ & $55^{\circ} 24 \mathrm{~W}$ \\
\hline 249 & 244 & $60^{\circ} 43 \mathrm{~S}$ & $45^{\circ} 48 W$ \\
\hline 264 & 468 & $61^{\circ} 57 \mathrm{~S}$ & $45^{\circ} 60 \mathrm{~W}$ \\
\hline 254 & 4455 & $63^{\circ} 57 \mathrm{~S}$ & $44^{\circ} 04 \mathrm{~W}$ \\
\hline 225 & 1948 & $62^{\circ} 16 \mathrm{~S}$ & $57^{\circ} 38 \mathrm{~W}$ \\
\hline 233 & 2297 & $61^{\circ} 38 \mathrm{~S}$ & $54^{\circ} 47 \mathrm{~W}$ \\
\hline \multicolumn{4}{|c|}{18 Nov-4 Dec, 1984} \\
\hline A & 1977 & $62^{\circ} 20 \mathrm{~S}$ & $57^{\circ} 50 \mathrm{~W}$ \\
\hline $\mathrm{B}$ & 504 & $62^{\circ} 14 \mathrm{~S}$ & $58^{\circ} 18 \mathrm{~W}$ \\
\hline $\mathrm{G}$ & 460 & $62^{\circ} 09 \mathrm{~S}$ & $58^{\circ} 24 \mathrm{~W}$ \\
\hline $\mathrm{I}$ & 92 & $63^{\circ} 12 \mathrm{~S}$ & $58^{\circ} 47 \mathrm{~W}$ \\
\hline $\mathrm{H}$ & 70 & $63^{\circ} 15 \mathrm{~S}$ & $56^{\circ} 51 \mathrm{~W}$ \\
\hline
\end{tabular}

decomposition of organic detritus as well as for their feasibility under shipboard conditions.

Activities of POM-solubilizing proteolytic, chitinolytic, and agarolytic enzymes were determined using dye release techniques described elsewhere (Reichardt 1986). Following incubation for up to $20 \mathrm{~h}$ of $10 \mathrm{mg}$ amounts of the solid substrates that were labelled with 'reactive' dyes, in $3 \mathrm{ml}$ aliquots of the enzyme extract, the assay mixture was centrifuged (15 min at $6000 \mathrm{~g}$ ) and the absorbance ( $660 \mathrm{~nm}$ ) of the dissolved dyelabelled depolymerization products in the supernatant measured photometrically. Blanks were treated with $1 \mathrm{ml}$ of $16 \%$ formaldehyde.

Activities of alkaline phosphatase and sulfatase in the triton-X100 extracts were derived from the hydrolysis of $2 \mathrm{mM}$ of $p$-nitrophenylphosphate and $p$-nitrophenylsulfate, respectively, (Morita \& Howe 1957. Reichardt et al. 1967, King \& Klug 1980) after incubation periods of 0.5 to $12 \mathrm{~h}$. After the addition of $1 \mathrm{ml}$ of $1 \mathrm{~N} \mathrm{NaOH}$ the absorbance of $p$-nitrophenol was determined spectrophotometrically at $410 \mathrm{~nm}$. Blanks contained $4 \%$ formaldehyde.

In vivo rates. Mineralization rates for ${ }^{14} \mathrm{C}(\mathrm{U})$-glucose or equimolar amounts of glucose labelled in positions $\mathrm{C}-1$ or $\mathrm{C}-3$ in other experiments were determined in $50 \mathrm{ml}$ serum flasks with $2 \mathrm{ml}$ aliquots of sediment slurry, i.e. suspension of $20 \mathrm{~cm}^{3}$ of sediment in $80 \mathrm{ml}$ of 0.1 um membrane filtered Antarctic seawater. The flasks were sealed with rubber serum bottle caps fitted with plastic rod and cup assemblies containing a fluted strip of Schleicher \& Schüll chromatography paper (Hobbie \& Crawford 1969, Morita et al. 1977). The slurries were incubated with $200 \mu \mathrm{I}(9.3 \mathrm{kBq})$ of ${ }^{14} \mathrm{C}$-(U)glucose (New England Nuclear, $144 \mathrm{kBq}$ umole ${ }^{-1}$ ) for 1 to $2 \mathrm{~h}$ (depending on the water depth). Samples treated with $4 \%$ of formaldehyde served as blanks. The incubation was terminated by acidification, i.e. injection of $1 \mathrm{~N} \mathrm{H}_{2} \mathrm{SO}_{4}$ to reach a final $\mathrm{pH}$ of 2.0 , followed by injection onto the paper strips of $0.15 \mathrm{ml}$ of phenethylamine as $\mathrm{CO}_{2}$ absorbent. Flasks were put on a rotary shaker for 20 min and left for at least $6 \mathrm{~h}$, before the paper strips were removed and placed in a toluene based scintillation fluid (Omnifluor, New England Nuclear). Radioactivity of the trapped ${ }^{14} \mathrm{CO}_{2}$ was measured in Beckman LS 100 and LS 1800 liquid scintillation counters. Quench corrections were based on external standards and channels' ratios.

Dark fixation rates of carbon dioxide were determined in $2 \mathrm{ml}$ of sediment slurry, i.e. suspension of $20 \mathrm{~cm}^{3}$ of sediment in $80 \mathrm{ml}$ of filter-sterilized Antarctic seawater, using capped $10 \mathrm{ml}$ polypropylene centrifuge tubes. From ampoules containing $370 \mathrm{kBq}$ per $\mathrm{ml}$ of $\mathrm{NaH}^{14} \mathrm{CO}_{3}$ (specific activity $=2183 \mathrm{kBq} !$ mole $^{-1}$ ) in $1.5 \mathrm{mM}$ of non-radioactive $\mathrm{NaHCO}_{3}$ adjusted to $\mathrm{pH} 10.2$ with $\mathrm{NaOH}, 0.25 \mathrm{ml}$ aliquots were mixed with 
the slurry and incubated in complete darkness for 1 to $4 \mathrm{~h}$, depending on the water depth. Blanks were poisoned with $20 \mathrm{mM}$ iodoacetamide. Incubation was terminated by adding $0.1 \mathrm{ml}$ of concentrated formaldehyde and $1 \mathrm{~N} \mathrm{H}_{2} \mathrm{SO}_{4}$ sufficient to lower the $\mathrm{pH}$ to 2.0 . After 2 rinses with ca $8 \mathrm{ml}$ of sterilized seawater and subsequent centrifugation (15 min at $6000 \mathrm{~g}$ ) the pellets were dried at $60^{\circ} \mathrm{C}$ and stored in a freezer.

Weighed amounts were combusted using an automatic Packard ${ }^{14} \mathrm{C}$-sample oxidizer for liquid scintillation counting. The radioactivity of the assimilated carbon was measured in a Beckman LS 100 liquid scintillation counter. Quench corrections were based on external standard and channels' ratios. Concentrations of total carbonate being available during the assay were derived from carbonate alkalinity according to Gargas (1980).

\section{RESULTS}

Vertical distribution patterns in the sediments indicated that most of the carbon turnover activities tested were limited to the bioturbated surface layers (1 to $10 \mathrm{~cm}$, Fig. 1). In assays carried out at an approximate in situ temperature of $0^{\circ} \mathrm{C}$, activities of POM-solubilizing enzymes such as scleroprotease and chitinase were usually at or below their detection limits. Maximal levels of these enzymes as found at Stn 233 were correlated with high concentrations of organic matter (41 mg ash-free dry weight per g dry weight). A turbidite layer containing $20 \mathrm{mg}$ of ash-free dry weight per $g$ dry weight at $15 \mathrm{~cm}$ depth lacked any detectable activity. Obviously cell-free enzymes had not been spread beyond their production sites. Except for scleroprotease, largely parallel trends were noted for both catabolic and anabolic reactions. According to this distribution pattern which recurred basically at all sampling stations, the 0 to $2 \mathrm{~cm}$ surface layers were chosen to collect the presumably most active material for experiments in temperature gradients.

High thresholds of detection for POM-solubilizing enzymes at ambient temperatures were closely related to their temperature characteristics (Fig, $2 \& 3$ ). Scleroprotease showed the steepest increase before reaching its temperature optimum between 40 and $55^{\circ} \mathrm{C}$ (Fig. 2). Similar temperature characteristics were noted for chitinase (Fig. 3) and agarase (not shown), although increments of activity at suboptimal temperatures were here less pronounced.

Cold adaptation of potentially extracellular hydrolases from Stn 264 was most pronounced for alkaline phosphatase with a temperature optimum around $30^{\circ} \mathrm{C}$ (Fig. 4) compared with $45^{\circ} \mathrm{C}$ for sulfatase (Fig. 5). Arrhenius constants for phosphatase and sulfatase amounted to 91.7 and $52.8 \mathrm{~kJ} \mathrm{~mole}^{-1}$, respectively.

Carbon dioxide evolution, representing mineralization as the final process of organic matter decomposition, was characterized by temperature optima around $20^{\circ} \mathrm{C}$ or lower (Fig. 6). This is far below the optimal temperature range of primary decomposition processes

Even stronger cold adaptation with temperature optima around $10^{\circ} \mathrm{C}$ was noted for dark fixation of $\mathrm{CO}_{2}$. In contrast to mineralization, temperature characteristics of this anabolic process showed considerable variations between different stations (Fig. 7).

When incubated at 2 and $20^{\circ} \mathrm{C}$ in a gradient of suboptimal substrate concentrations, none of the

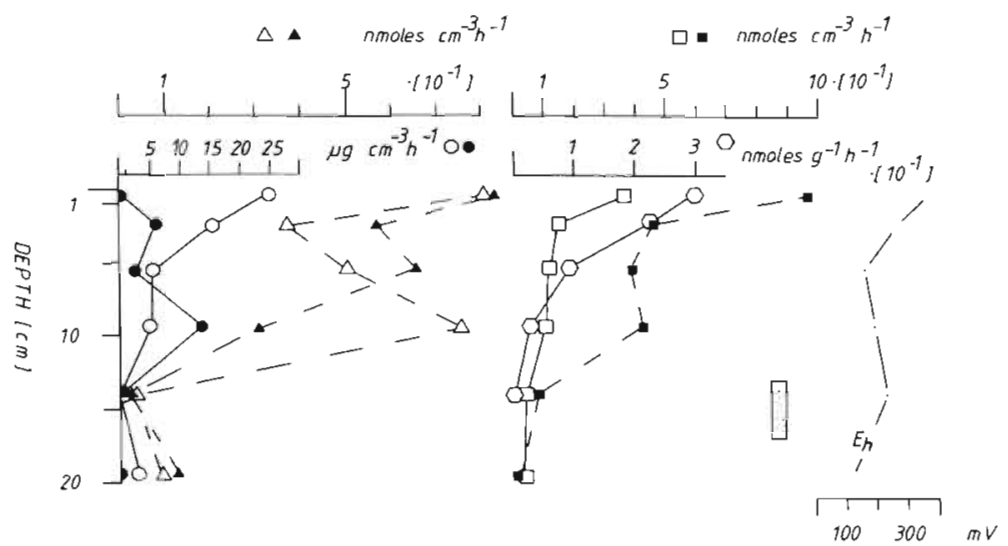

Fig. 1 Vertical profiles of different microbial activities (at $0^{\circ} \mathrm{C}$ ) contributing to carbon turnover in bioturbated sediment at $2297 \mathrm{~m}$ water depth (Stn 233). Chitinase (0), scleroprotease ( $)$, alkaline phosphatase ( and acetate ( $\mathbf{D}$ ), rates of $\mathrm{CO}_{2}$ dark fixation (O). Position of turbidite indicated by small dotted column, redox potential (Eh) 


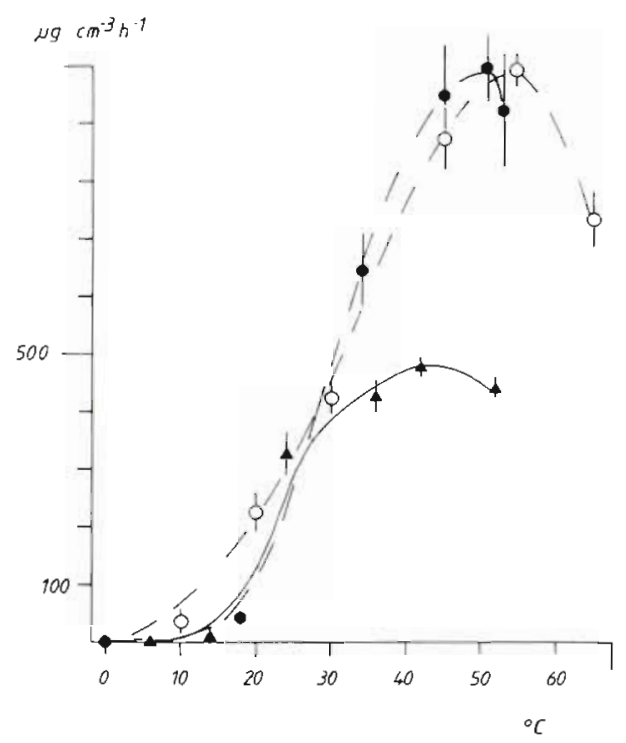

Fig. 2. Temperature dependence of scleroprotease activity from Stns $249(0), \mathrm{H}(\bullet)$, and $\mathrm{G}(\mathbf{\Delta})$; further details in Table 1

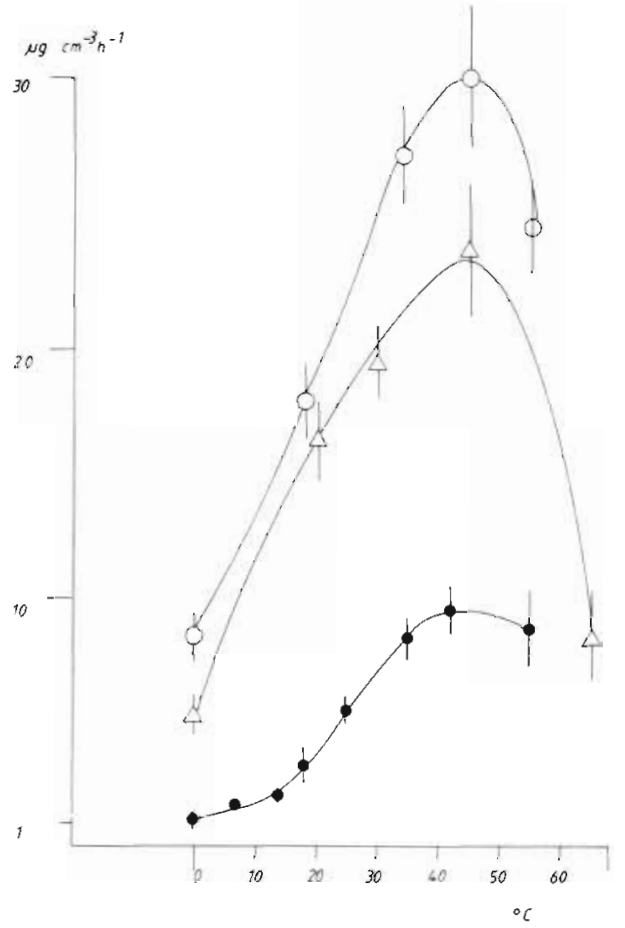

Fig. 3. Temperature dependence of chitinase activity from Stns $249(\Delta), \mathrm{H}(0)$, and $\mathrm{G}(\bullet)$; further details in Table 1

activities tested exhibited $k_{M}$ values sufficiently different to qualify as potential indicators of temperature adaptation.

Likewise, calculation of activation energies $E_{A}$ from Arrhenius plots (ln $k=-E_{A} / R T+$ const.) indicated insignificant differences between sediments from the Antarctic and the Baltic Sea, as far as glucose minerali-

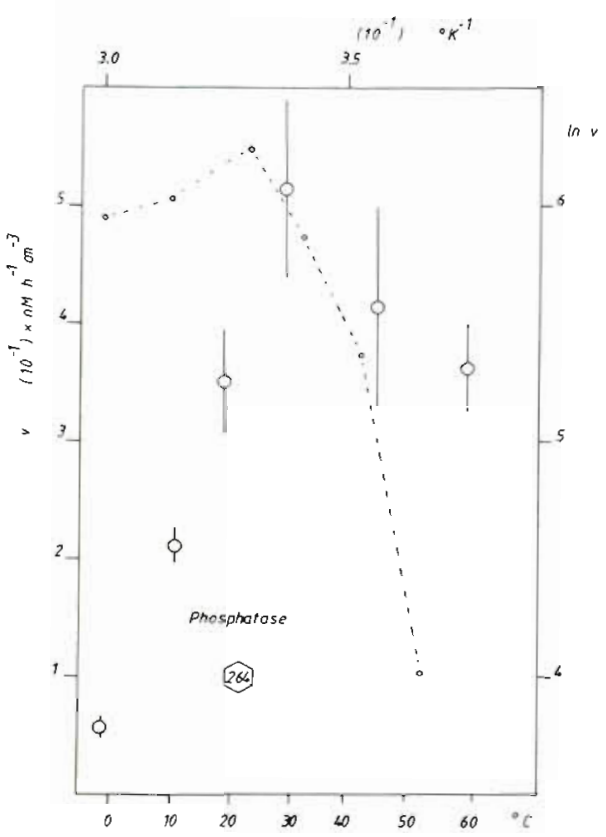

Fig. 4. Temperature dependence with Arrhenius plot for alkaline phosphatase from Stn 264; further details in Table 1

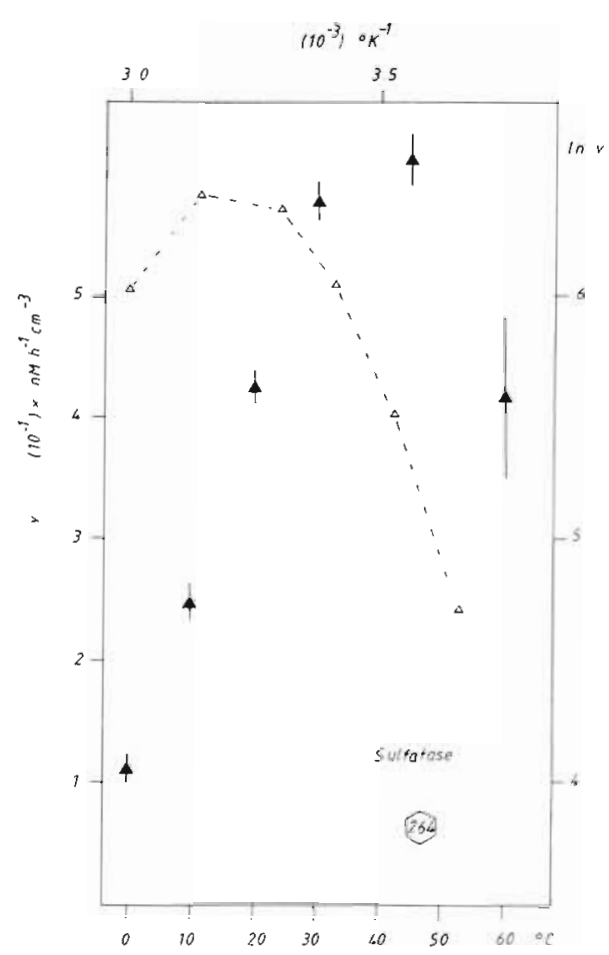

Fig. 5. Temperature dependence with Arrhenius plot for sulfatase from Stn 264; further details in Table 1

zation and $\mathrm{CO}_{2}$ assimilation were concerned. Yet, for scleroprotease activity in Antarctic sediments, $\mathrm{E}_{\mathrm{A}^{-} \text {-val- }}$ ues were significantly higher, suggesting an unexpected 'negative' cold adaptation (Table 2). 


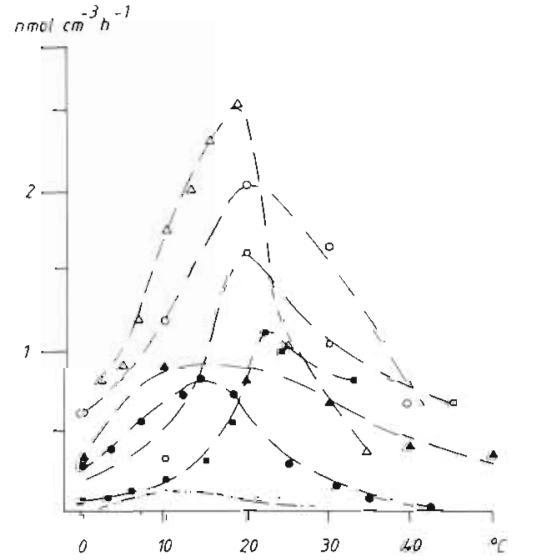

Fig. 6. Temperature dependence of mineralization rates for

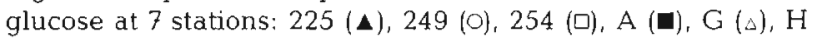
$(\bullet)$, I (•); further details in Table 1

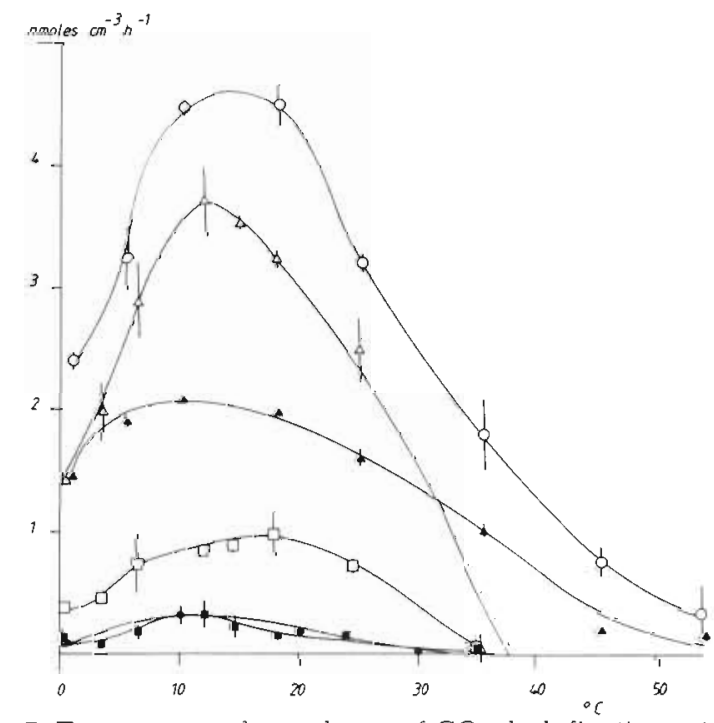

Fig. 7. Temperature dependence of $\mathrm{CO}_{2}$ dark fixation rates at 6 stations: $254(\mathbf{\square}), \mathrm{A}(\mathbf{\Delta}), \mathrm{B}(\mathrm{O}), \mathrm{G}(\Delta), \mathrm{H}(\square), \mathrm{J}(\bullet)_{\text {; further }}$ details in Table 1

Table 2. Temperature optima (T opt.) and activation energies $\left(\mathrm{E}_{\mathrm{A}}\right)$ for selected catabolic and anabolic activities involved in carbon turnover in Antarctic sediments. Data from Kiel Bay sediment for end of winter (in brackets) included for comparison

\begin{tabular}{|lccc|}
\hline & $\begin{array}{c}\text { Scleroprotease } \\
\text { activity }\end{array}$ & $\begin{array}{c}\text { Glucose } \\
\text { mineralization }\end{array}$ & $\begin{array}{c}\mathrm{CO}_{2} \text {-dark } \\
\text { assimilation }\end{array}$ \\
\hline $\begin{array}{l}\text { Number of } \\
\text { stations }\end{array}$ & 10 & 9 & 8 \\
$T_{\text {opt }}\left({ }^{\circ} \mathrm{C}\right)$ & $(2)$ & $(2)$ & $(2)$ \\
Mean value & $49 \pm 7$ & $17 \pm 5$ & $16 \pm 7$ \\
$\mathrm{SD}$ & $(50 \pm 14)$ & $(30 \pm 3)$ & $(20 \pm 3)$ \\
$\mathrm{E}_{\mathrm{A}}(\mathrm{kJ}$ mole & $-1)$ \\
Mean value & $209 \pm 157$ & $44 \pm 23$ & $47 \pm 10$ \\
$\mathrm{SD}$ & $(37 \pm 18)$ & $(42 \pm 27)$ & $(50 \pm 9)$ \\
\hline
\end{tabular}

Another approach to detect cold adaptation was based on metabolic pathways for glucose mineralization at $2^{\circ} \mathrm{C}$ vs $18^{\circ} \mathrm{C}$ as indicated by the $\mathrm{C}-3: \mathrm{C}-1$ ratio of position-labelled glucose contributing to the evolution of $\mathrm{CO}_{2}$. In contrast to Baltic Sea sediments, at the 3 Antarctic stations tested this ratio was slightly enhanced at the lower temperature. This could indicate a moderate preference for the glycolytic pathway (Table 3).

Table 3. Influence of temperature on molar ratio $\mathrm{C} 3: \mathrm{C} 1$ of $\mathrm{CO}_{2}$ evolved from equimolar quantities of ${ }^{14} \mathrm{C}$-glucose labelled in C1- and C3-position, respectively

\begin{tabular}{|lrrrr|}
\hline \multicolumn{3}{c}{ Origin of sediment } & \multicolumn{2}{c|}{ Assay temperature: } \\
Location & Station & Depth (m) & $2 \pm 2{ }^{\circ} \mathrm{C}$ & $18 \pm 2{ }^{\circ} \mathrm{C}$ \\
\hline Antarctic & 225 & 1948 & 0.82 & 0.75 \\
Antarctic & 264 & 468 & 0.52 & 0.40 \\
Antarctic & 270 & 113 & 2.72 & 2.33 \\
Kiel Bay & & 18 & 1.03 & 1.35 \\
\hline
\end{tabular}

\section{DISCUSSION}

Accumulation rates for organic carbon (comprising both living and dead organic matter) in the Bransfield Strait and adjacent shelf sediments amount to $17 \mathrm{~g} \mathrm{C}$ $\mathrm{m}^{-2} \mathrm{yr}^{-1}$ or 9 to $28 \%$ of the primary production in the surface waters (Wefer, pers. comm.). These are extremely high compared with other oceanic regions with oxygenated bottom waters. On the other hand, earlier suggestions that organic matter in polar waters accumulates due to inhibited microbial degradation (Sorokin 1970), have later been discounted in view of excellent temperature adaptations reported for the utilization, viz. uptake, of dissolved organic substrates by Antarctic microheterotrophs (Gillespie et al. 1976 , Holm-Hansen et al. 1977, Morita et al. 1977. Hodson et al. 1981).

Nevertheless, uptake of dissolved organic substrates alone is an insufficient measure of microbial decomposition. Although the input of organic carbon to the Antarctic sea floor depends largely on sedimenting POM, no data are available concerning the decomposition of POM into DOM and its temperature characteristics. A similar lack of previous data was apparent for carbon IN RUHEineralization and dark fixation of $\mathrm{CO}_{2}$ in aphotic Antarctic sediments.

Proof whether the carbon budget is balanced is difficult to obtain. This is also due to the spatial separation of primary production in the euphotic water column and remineralization often taking place at the sea bottom (Müller \& Suess 1979). In principal, it is important whether equal efficiencies can be taken for 
granted in both biosynthetic and catabolic biogeochemical pathways. To prove this, responses to temperature in particular qualify as an unambiguous indicator of biological activities (Radmer \& Kok 1979).

Compared with temperature characteristics of individual enzymes or single organisms, little is known about cold adaptation at the holistic level concerning the major biogeochemical pathways in an ecosystem. Cold adaptation at this level is usually described by temperature optima and temperature-dependent increments of rates or enzyme activities which may be expressed as $Q_{10}$ values or Arrhenius constants (e.g. Baross \& Morita 1978, Fuhrman \& Azam 1983).

As yet, temperature characteristics of anabolic pathways such as dark fixation of $\mathrm{CO}_{2}$ have not been reported for Antarctic sediments. This mainly chemosynthetic pathway of primary biosynthesis revealed the highest degree of cold adaptation during the present investigation. Temperature optima usually around $10^{\circ} \mathrm{C}$ and below were only slightly higher than those reported for chlorophyll a-specific $\mathrm{CO}_{2}$ fixation rates of Antarctic phytoplankton from the Bransfield Strait (Neori \& HolmHansen 1982, Tilzer \& Dubinsky 1987). Still lower temperature optima (a plateau formed at temperatures higher than $0^{\circ} \mathrm{C}$ ) are known for Arctic phytoplankton (Li et al. 1984).

Despite their high degree of cold adaptation, $\mathrm{CO}_{2}$ dark fixation rates were still suboptimal at ambient temperatures and far from showing a uniform temperature characteristic in different sediments. Particularly noteworthy is an extremely high temperature optimum (ca $55^{\circ} \mathrm{C}$ ) for dark fixation that was recorded for sediment from $1980 \mathrm{~m}$ depth in the Bransfield Strait where submarine volcanism is likely to play a role (Reichardt unpubl., Suess pers. comm.).

In Antarctic waters photosynthetic $\mathrm{CO}_{2}$ fixation and microheterotrophic uptake of organic carbon share similar temperature characteristics (Gillespie et al. 1976, Holm-Hansen et al. 1977, Morita et al. 1977. Hodson et al. 1981). Corresponding data for carbon mineralization rates are lacking. With temperature optima around $20^{\circ} \mathrm{C}$, cold adaptation of glucose mineralization (Fig. 6) was only moderately expressed and less pronounced than previously reported for the uptake of organic carbon.

In psychrophilic bacterial isolates, key catalysts of mineralization such as NADH dehydrogenases possessed temperature optima between 20 and $25^{\circ} \mathrm{C}$ (Takada et al. 1981). As psychrophilic bacteria may be considered as the chief microheterotrophs involved in organic matter mineralization in the investigated environment, it is noteworthy that their maximal growth temperatures (Morita 1975) coincide roughly with the temperature optima found for glucose mineralization rates.
Bacterial mineralization of POM requires conversion to dissolved compounds by extracellular solubilizing enzymes. Temperature optima between 45 and $55^{\circ} \mathrm{C}$ for proteolytic and chitinolytic activities (Fig. 2 \& 3) suggested a striking lack of cold adaptation. This concurs with the poor cold adaptation of extracellular proteases as well as chitinases in pure cultures of psychrophilic bacteria (McDonald et al. 1963, Weimer \& Morita 1974, Helmke \& Weyland 1986). As compared with sediments from the Baltic Sea, no significant differences were noted with respect to temperature optima. Increased activation energies for Antarctic scleroprotease indicated even a higher energy barrier for scleroprotein degradation in an environment being otherwise better adapted to cold temperatures (Table 2). This would strongly support the idea that conversion of POM to DOM is, more than other pathways of organic matter degradation, limited and controlled by temperature (Godshalk \& Wetzel 1977).

Side reactions such as desulfatation of organic compounds (Weigl \& Yaphe 1966, Fitzgerald 1976) were also affected by relatively high temperature optima $\left(45^{\circ} \mathrm{C}\right)$ of sulfatase in Antarctic sediments, although $60^{\circ} \mathrm{C}$ temperature optima have been reported for sediments from lower latitudes (Oshrain \& Wiebe 1979). A considerably lower optimum $\left(30^{\circ} \mathrm{C}\right)$ characterized alkaline phosphatase from the same source (Fig. 4). Heat-sensitive alkaline phosphatases have also been isolated from Antarctic marine bacteria (Koberi et al. 1984). Consequently, there is evidence for mechanisms of cold adaptation of certain hydrolyzing enzymes from permanently cold environments that imply a downshift of their temperature optima.

Whereas temperature optima provide most essential clues to thermal efficiencies of enzymatic reactions, further aspects of temperature compensation must not be neglected. Cold adaptation at the kinetic level may not only affect $Q_{10}$ values or activation energies, but also substrate affinities for enzymes and their interactions with allosteric effectors or inhibitors (Hochachka \& Somero 1973). Attempts to compare Michaelis-Menten constants $\left(\mathrm{k}_{\mathrm{M}}\right)$ for alkaline phosphatase, sulfatase and scleroprotease in sediment extracts incubated at 0 and $20^{\circ} \mathrm{C}$ proved useless as long as the contribution to $\mathrm{k}_{\mathrm{M}}$ of substrates already present in the extracts remained unknown. In corresponding experiments with psychrophilic bacterial isolates, cold-induced increases of the substrate affinities $\left(1 / \mathrm{k}_{M}\right)$ occurred occasionally, but increments were smaller than 1 order of magnitude. Obviously, a more extended kinetic approach is needed to evaluate the quantitative and qualitative changes affecting both enzymes and substrates as a result of the in situ physico-chemical conditions in sediments, where sorption plays a predominant role. 
It has been postulated that temperature compensating changes affecting the enzyme activity are primarily associated with pathways of energy production (Hazel \& Prosser 1974, Somero 1978). The differences noted for glucose mineralization in Antarctic and Baltic Sea sediments (Table 2) support this view.

For decomposition by extracellular enzymes, on the other hand, alternative pathways of temperature adaptation may be hypothesized. Instead of changing enzyme activities qualitatively, acclimation may be achieved by increasing the production of enzymes or iso-enzymes. Levels of scleroprotease, chitinase, alkaline phosphatase or sulfatase in sediments from the Antarctic and the Baltic, however, did not suggest that accumulation of enzymes was much stronger in the permanently cold environment (Reichardt 1986, unpubl.). Nevertheless, considering the inherent patchiness in these ecosystems, comparing activity levels in sediments appears to be an extremely insufficient approach to estimate enzyme production rates. On the other hand, there is experimental evidence for increased production of scleroprotease and, partly, chitinase at in situ temperatures by psychrophilic bacteria from investigated Antarctic sediments (Reichardt unpubl.). The existence of such mechanisms, which counteract a lack of temperature compensation at the activity level, may also be postulated for corresponding extracellular enzymes in the sediment.

Furthermore, acclimation to cold temperatures may be acquired by changing the pathways for key metabolic processes (Hochachka 1967). In particular, work on psychrophilic bacteria suggests a reduction of the electron transport system in favor of fermentative pathways (Rüger 1984). Limited proof of the significance of such mechanisms in permanently cold marine sediments can be gained from radiorespirometry using glucose labelled with ${ }^{14} \mathrm{C}$ in different positions (Katz \& Wood 1960, Wang 1967). First results suggested in fact a slightly increased generation of $\mathrm{CO}_{2}$ from the $\mathrm{C}-3$ position at the lower temperature when the assays were carried out with Antarctic sediments (Table 3). Detailed enzymatic investigations are necessary to corroborate this indication of metabolic cold adaptation of fermentative pathways. As far as differences between glucose respiration in euhaline Antarctic sediments and estuarine Kiel Bay sediments are concerned, an increasing contribution of the Embden-Meyerhof pathway (C-3/ C-1>1) may be expected at low salinities (Griffiths \& Morita 1973).

Irrespective of thermal characteristics, there were fundamental differences between single depolymerizing enzyme activities involved in primary decomposition processes and the complex enzymatic machinery being responsible for $\mathrm{CO}_{2}$ turnover. The largely membrane-bound functions of the latter required in vivo measurements, whereas extracellular enzymes had to be extracted from the sediment. Extracellular enzymes can be stabilized and survive in sediments over long time periods (Skujins \& McLaren 1968, Nissenbaum \& Serban 1987).

As discussed above, lacking cold adaptation at the activity level may be counterbalanced by cold-adapted enzyme synthesis. Due to various mechanisms of enzymatic regulation, interferences from variables other than temperature are likely to be expected in this case (Somero et al. 1983).

In conclusion, the consequences of the apparent lack of cold adaptation among certain extracellular POMdegrading enzyme activities become less severe, as the benthic carbon flow is controlled by temperature-independent mechanisms. This does not preclude, however, that, under certain circumstances, decomposition of detrital POM becomes a temperature-controlled process as stated by Godshalk \& Wetzel (1977).

Four of the Antarctic stations sampled were at water depths below $1000 \mathrm{~m}$ where the impact of deep-sea hydrostatic pressure has to be taken into account. Under these conditions decomposition of POM is extremely slow, unless mediated by macrofaunal disruption and digestion (Jannasch et al. 1971, Sieburth \& Dietz 1974, Hargrave 1976, Jannasch \& Wirsen 1983). While biochemical adaptations to the hydrostatic pressure regime in the deep sea are well documented (Yayanos et al. 1979, Cahet \& Sibuet 1986, Helmke \& Weyland 1986), recalcitrance of sedimenting POM increases with residence time in the water column (Rice 1982) and with increasing water depth (Wakeham et al. 1984). In any case, solubilization rates for POM depend on the number of attachment sites for pertinent enzymes on the surface of their particulate substrates (Reese 1977). It is therefore conceivable that in the heavily bioturbated Antarctic seabottom, reworking of sediments and their POM load by burrowing infauna may play an even greater role for the efficiency of POM degradation than enzymatic cold adaptation at the activity level.

Acknowledgements. This investigation was funded by a grant from the 'Deutsche Forschungsgemeinschaft' (Re 271/15-1).

\section{LITERATURE CITED}

Arnaud, P. M. (1977). Adaptations within the Antarctic marine benthic ecosystem. In: Llano, G. A. (ed.) Adaptations within Antarctic ecosystems. Gulf Publ., Houston, p. 135-157

Baross, J. A., Morita, R. Y. (1978). Microbial life at low tem. peratures: ecological aspects. In: Kushner, D. J. (ed.) Microbial life in extreme environments. Academic Press, London, p. 9-71

Cahet, G., Sibuet, M. (1986). Activité biologique en domaine profond: transformations biochimiques in situ de composés organiques marqués au carbone-14 à l'interface eau-sédi- 
ment par 2000 m de profondeur dans le golfe de Gascogne Mar. Biol. 90: 307-315

Fitzgerald, J. W. (1976). Sulfate ester formation and hydrolysis: a potentially important yet often ignored aspect of the sulfur cycle of aerobic soils. Bact. Rev. 40: 698-721

Fuhrmann, J. A., Azam, F. (1983). Adaptations of bacteria to marine sub-surface waters studied by temperature response. Mar, Ecol. Prog. Ser. 13: 95-98

Gargas, E. (1980). A manual for phytoplankton primary production studies in the Baltic, 2nd edn. The Baltic Marine Biologists Publ. No. 2

George, R. Y. (1977). Dissimilar and similar trends in Antarctic and Arctic marine benthos. In: Dunbar, M. J. (ed.) Polar oceans. Arctic Institute of North America, Calgary, Alberta, p. 391-407

Gillespie, P. A., Morita, R. Y., Jones, L. P. (1976). The heterotrophic activity for amino acids, glucose and acetate in Antarctic waters. J. oceanogr. Soc. Japan 32: 74-82

Godshalk, G. L., Wetzel, R. G. (1977). Decomposition of macrophytes and the metabolism of organic matter in sediments. In. Golterman, H. L. (ed.) Interactions between sediments and freshwater. Junk Publishers, The Hague, p. $258-264$

Griffiths, R. P., Morita, R. Y. (1973). Salinity effects on glucose uptake and catabolism in the obligately psychrophilic marine bacterium Vibrio marinus. Mar. Biol. 23: 177-182

Hargrave, B. T (1976). The central role of invertebrate faeces in sediment decomposition. In: Anderson, J. M., MacFadyen, A. (ed.) The role of terrestrial and aquatic organisms in decomposition processes. Blackwell, Oxford, p. $301-321$

Hazel, J. R., Prosser, C. L. (1974). Molecular mechanisms of temperature compensation in poikilotherms. Physiol. Rev. 54: 620-677

Helmke, E., Weyland, H. (1986). Effect of hydrostatic pressure and temperature on the activity and synthesis of chitinases of Antarctic Ocean bacteria. Mar. Biol. 91: 1-7

Hobbie, J. E., Crawford, C. C. (1969). Respiration corrections for bacterial uptake of dissolved organic compounds in natural waters. Limnol. Oceanogr 14:528-532

Hochachka, P. W (1967). Organization of metabolism during temperature compensation. In: Prosser, C. L. (ed.) Molecular mechanism of temperature adaptation. Washington, D.C., p. $177-203$

Hochachka, P. W., Somero, G. N. (1973). Strategies of biochemical adaptation. Saunders, Philadelphia

Hodson, R. E., Azam, F., Carlucci, A. F., Fuhrman, J. A., Karl, D. M., Holm-Hansen, O. (1981). Microbial uptake of dissolved organic matter in McMurdo Sound, Antarctica. Mar. Biol. 61. 89-94

Holm-Hansen, O., Azam, F., Carlucci, A. F., Hodson, R. E. Karl, D. M. (1977). Microbial distribution and activity in and around McMurdo Sound. Antarct. J. U.S. 12: 29-32

Jannasch, H. W., Eimhjellen. K., Wirsen, C. O., Farmanfarmaian, A. (1971). Microbial degradation of organic matter in the deep sea. Science 171: 672-675

Jannasch, H. W. Wirsen, C. O. (1983). Microbiology of the deep sea. In: Rowe, G. T (ed.) The sea, Vol. 8, Deep-sea biology. Wiley, New York, p. 231-259

Katz, J., Wood, H. G. (1960). The use of glucose- $-{ }^{14} \mathrm{C}$ for the evaluation of the pathways of glucose metabolism. J. biol. Chem. 235: 2165-2177

King, G. M., Klug, M. J. (1980). Sulfhydrolase activity in sediments of Wintergreen Lake, Kalamazoo County, Michigan. Appl environ. Microbiol. 39: 950-956

Kobori, H., Sullivan, C. W., Shizuya, H. (1984). Heat-labile alkaline phosphatase from Antarctic bacteria: rapid 5'end- labeling of nucleic acids. Proc. natn. Acad. Sci. U.S.A. 81 : 6691-6695

Li, W. K. W. Smith, J. C, Platt, T (1984). Temperature response of photosynthetic capacity and carboxylase activity in Arctic marine phytoplankton. Mar. Ecol. Prog. Ser. 17: $237-243$

McDonald, I. J., Quadling, C., Chambers, A. K. (1963). Proteolytic activity of some cold-tolerant bacteria from Arctic sediments. Can. J. Microbiol. 9: 303-315

Morita, R. Y (1975). Psychrophilic bacteria. Bact. Rev. 39: $144-167$

Morita, R. Y., Griffiths, R. P., Hayasaka, S. S. (1977). Heterotrophic activity of microorganisms in Antarctic waters. In: Llano, G. A. (ed.) Adaptations within Antarctic ecosystems. Gulf Publ., Houston, p. 99-113

Morita, R. Y., Howe, R. A. (1957). Phosphatase activity by marine bacteria under hydrostatic pressure. Deep Sea Res. 4: 254-258

Müller, P. J., Suess, E. (1979). Productivity, sedimentation rate, and sedimentary organic matter in the oceans. I. Organic carbon preservation. Deep Sea Res. 26A: 1347-1362

Neori, A. S., Holm-Hansen, O. (1982). Effect of temperature on rate of photosynthesis in Antarctic phytoplankton. Polar Biol. 1: 33-38

Nissenbaum, A., Serban, A. (1987). Enzymatic (?) activity associated with humic substances in deep sediments from the Cariaco Trench and Walvis Ridge. Geochim. cosmochim. Acta 51: $373-378$

Oshrain, R. L., Wiebe, W. J. (1979). Arylsulfatase activity in salt marsh soils. Appl. environ. Microbiol. 38: 337-340

Pomeroy, L. R, Wiebe, W. J., Frankenberg, D., Hendricks, C., Layton, W. L. (1969). Metabolism of total water column. Antarct. J. U.S. 5: $149-150$

Radmer, R. J., Kok, B. (1979). Rate-temperature curves as an unambiguous indicator of biological activity in soil. Appl. environ. Microbiol. 38: 224-228

Reese, D. T (1977). Degradation of polymeric carbohydrates by microbial enzymes. In: Loewus, F. A., Runeckles, B. C. (ed.) The structure, biosynthesis and biodegradation of wood. Plenum Press, New York, p. 311-367

Reichardt, W. (1986). Enzymatic potential for decomposition of detrital biopolymers in sediments from Kiel Bay. Ophelia 26: $369-384$

Reichardt, W., Overbeck, J., Steubing, L. (1967). Free dissolved enzymes in lake waters. Nature. Lond. 216: 1345-1347

Rice, D. L. (1982). The detritus nitrogen problem: new observations and perspectives from organic geochemistry. Mar. Ecol. Prog. Ser. 9: 153-162

Rüger, H. J. (1984). Temperature effects on respiratory electron transport system (ETS) in psychrophilic and mesophilic marine bacteria. Veröff. Inst. Meeresforsch Bremerhaven 20: 29-40

Sieburth, J. McN. Dietz, A. S. (1974). Biodeterioration in the sea and its inhibition. In: Colwell, R. R., Morita, R. Y. (ed.) Effect of ocean environment on microbial activities. Univ Park Press. Baltimore, p 318-326

Skujins, J., McLaren, A. D. (1968). Persistence of enzymatic activities in stored and geologically preserved soils. Enzy. mologia 34: $213-225$

Somero, G. N. (1978). Temperature adaptation of enzymes: biological optimization through structure-function compromises. A. Rev. Ecol. Syst. 9. 1-29

Somero, G. N., Siebenaller, J. F., Hochachka, P. W (1983). Biochemical and physiological adaptations of deep-sea animals. In: Rowe, G. T (ed.) The sea, Vol. 8, Deep-sea biology. Wiley, New York, p. 261-330

Sorokin, Ju. J. (1970). K kolicestvenno ocenke roli bakterio- 
planktona $\mathrm{v}$ krugovorotje organiceskovo vescestva $\mathrm{v}$ tropiceskich vodach okeana. Dokl. Akad. Nauk SSSR 193: 923-925

Takada, Y., Fukunaga, N., Sasaki, S. (1981). Temperature dependence and distribution of NADH dehydrogenase in a psychrophilic bacterium, Vibrio sp. strain ABE-1. J. gen. appl. Microbiol., Tokyo, 27: 327-337

Tilzer, M. M., Dubinski, Z. (1987). Effects of temperature and day length on the mass balance of Antarctic phytoplankton. Polar Biol. 7: 35-42

Wakeham, S. G., Lee, C., Farrington, J. W., Gagosian, R. B. (1984). Biogeochemistry of particulate organic matter in the oceans: results from sediment trap experiments. Deep Sea Res. 31: $509-528$
Wang, C. H. (1967). Radiorespirometry. Meth. Biochem. Anal. 15: $311-368$

Weigl, J., Yaphe, W. (1966). Glycosulphatase of Pseudomonas carrageenovora. Desulphation of disaccharide from $\mathrm{k}$ carrageenan. Can. J. Microbiol. 12: 874-876

Weimer, M. S., Morita, R. Y. (1974). Temperature and hydrostatic pressure effects on gelatinase activity of a Vibrio sp. and partially purified gelatinase. Z. allg. Mikrobiol. 14: $719-725$

Yayanos, A. A., Dietz, A. S., Van Boxtel, R. (1979). Isolation of a deep-sea barophilic bacterium and some of its growth characteristics. Science 205: 808-810

This article was submitted to the editor; it was accepted for printing on July 15, 1987 